\title{
PENGARUH MODEL PEMBELAJARAN KOOPERATIF TIPE TEAMS GAMES TOURNAMENT (TGT) BERBANTUAN MEDIA GAME ONLINE TERHADAP PEMAHAMAN KONSEP DAN PENALARAN MATEMATIS SISWA Oleh: \\ Emay Aenu Rohmah ${ }^{1}$, Wahyudin ${ }^{2}$ \\ Universitas Pendidikan Indonesia
}

\begin{abstract}
This research is motivated by the problems of low capacity of understanding of the concept and students' mathematical reasoning. This study aimed to examine the increased ability of understanding mathematical concepts and reasoning of students using cooperative learning model of online games media aided TGT. This study is a quasi-experimental study research design pretest posttest control group. The research instrument used is to test the ability of understanding the concepts and mathematical reasoning. The results showed that 1) There are differences in the ability of understanding mathematical concepts of students who received aided cooperative learning TGT media online games with students who received direct instruction. 2) There is no difference in mathematical reasoning skills students acquire aided cooperative learning TGT media online games with students who received direct instruction. 3) There are differences in the increase in the ability of understanding mathematical concepts of students who received aided cooperative learning TGT media online games with students who received direct instruction. 4) There are differences in the increase of mathematical reasoning abilities of students who received aided cooperative learning $T G T$ media online games with students who received direct instruction. Based on these results can be concluded that cooperative learning TGT media aided online games can improve understanding of concepts and mathematical reasoning students.
\end{abstract}

Keywords: Cooperative Learning TGT Type, Online Game Media, Conceptual Comprehension

\begin{abstract}
Abstrak:Penelitian ini dilatarbelakangi oleh permasalahan rendahnya kemampuan pemahaman konsep dan penalaran matematis siswa. Penelitian ini bertujuan untuk menelaah peningkatan kemampuan pemahaman konsep dan penalaran matematis siswa dengan menggunakan model pembelajaran kooperatif tipe TGT berbantuan media game online. Penelitian ini merupakan studi kuasi eksperimen dengan desain penelitian pretest posttest control group design. Instrumen penelitian yang digunakan adalah tes kemampuan pemahaman konsep dan penalaran matematis. Hasil penelitian menunjukkan bahwa 1) Tidak terdapat perbedaan kemampuan pemahaman konsep matematis siswa yang memperoleh pembelajaran kooperatif tipe TGT berbantuan media game online dengan siswa yang memperoleh pembelajaran langsung. 2) Tidak terdapat perbedaan kemampuan penalaran matematis siswa yang memperoleh pembelajaran kooperatif tipe TGT berbantuan media game online dengan siswa yang memperoleh pembelajaran langsung. 3) Terdapat perbedaan peningkatan kemampuan pemahaman konsep matematis siswa yang memperoleh pembelajaran kooperatif tipe TGT berbantuan media game online dengan siswa yang memperoleh pembelajaran langsung. 4) Terdapat perbedaan peningkatan kemampuan penalaran matematis siswa yang memperoleh pembelajaran kooperatif tipe TGT berbantuan media game online dengan siswa yang memperoleh pembelajaran langsung. Berdasarkan hasil tersebut dapat dibuat kesimpulan bahwa pembelajaran kooperatif tipe TGT berbantuan media game online dapat meningkatkan kemampuan pemahaman konsep dan penalaran matematis siswa.
\end{abstract}

Kata Kunci: Pembelajaran Kooperatif Tipe TGT, Media Game online, Pemahaman Konsep dan Penalaran Matematis.

\section{PENDAHULUAN}

\footnotetext{
${ }^{1}$ Mahasiswa S2 Prodi Pendidikan Dasar UPI Bandung, Email: my ainu4@yahoo.com

2 Dosen Universitas Pendidikan Indonesia
} 
Pembelajaran matematika di sekolah dasar sebagai bagian dari sistem pendidikan nasional, menurut kurikulum 2006, bertujuan antara lain agar siswa memiliki kemampuan yang dapat dialihgunakan melalui kegiatan matematika. Dalam kurikulum 2006, mata pelajaran matematika memuat rincian topik, kemampuan dasar matematika dan sikap yang diharapkan dimiliki siswa. Secara garis besar kemampuan dasar matematika dapat diklasifikasikan dalam lima standar, yaitu (1) mengenal, memahami, dan menerapkan konsep, prosedur, prinsip dan ide matematika (2) menyelesaikan masalah matematika (mathematical problem solving) (3) bernalar matematika (mathematical reasoning) (4) melakukan koneksi matematika (mathematical connection) dan (5) komunikasi matematika (mathematical communication) (NCTM, 2000).

Kurikulum Tingkat Satuan Pendidikan (Depdiknas, 2006, hlm. 30) menyatakan bahwa tujuan mata pelajaran matematika di sekolah dasar, diantaranya, yaitu: 1) Memahami konsep matematika, menjelaskan keterkaitan antara konsep dan mengaplikasikan konsep atau algoritma secara luwes, akurat, efisien dan tepat dalam memecahkan masalah, 2) Menggunakan penalaran pada pola dan sifat, melakukan manipulasi matematika dalam membuat generalisasi, menyusun bukti, atau menjelaskan gagasan dan pernyataan matematika.

Berdasarkan tujuan diatas, pemahaman konsep dan penalaran matematis merupakan kompetensi yang harus dikembangkan dalam diri siswa. Pemahaman konsep matematis merupakan landasan penting untuk berpikir dalam menyelesaikan permasalahan matematika atau permasalahan sehari-hari. Siswa yang dapat memahami konsep matematika dengan baik, akan lebih mudah mengaplikasikannya dalam berbagai masalah kehidupan. Selain kemampuan pemahaman konsep dalam upaya mengembangkan sikap ilmiah siswa, juga diperlukan kemampuan penalaran matematis. Istilah penalaran matematis dalam beberapa literatur disebut dengan mathematical reasoning. Brodie (2010, hlm 7) menyatakan bahwa, "Mathematical reasoning is reasoning about and with the object of mathematics." Pernyataan tersebut dapat diartikan bahwa penalaran matematis adalah penalaran mengenai objek matematika.

Uraian yang telah dipaparkan tersebut menunjukkan pentingnya kemampuan pemahaman konsep dan penalaran matematis dikembangkan dalam diri siswa. Pada kenyataannya, selalu ada hambatan dalam pembelajaran matematika, salah satunya matematika dianggap pelajaran yang sulit. Sebagaimana diungkapkan oleh Wahyudin (2008, hlm. 1) bahwa matematika adalah pelajaran yang sulit dipelajari maupun diajarkan, hal ini dikarenakan matematika merupakan pelajaran yang sangat hierarkis. Sehingga untuk mempelajari materi baru seringkali memerlukan pemahaman yang baik tentang beberapa materi sebelumnya. Demikian pula dengan pendapat Ruseffendi (2006) yang menyatakan bahwa anak-anak menyenangi matematika hanya pada permulaan mereka berkenalan dengan matematika yang sederhana. Makin tinggi tingkatan sekolahnya dan makin sukar materi yang dipelajarinya akan semakin berkurang minatnya.

Riyanto (2011, hlm. 113) menyatakan bahwa salah satu penyebab kurangnya kemampuan penalaran dan prestasi matematika siswa adalah proses pembelajaran yang dilakukan oleh guru di kelas kurang melibatkan siswa dalam proses pembelajaran atau tidak terjadi diskusi antara siswa dengan siswa dan siswa dengan guru. Dalam proses 
pembelajaran, siswa tidak mengeksplorasi, menemukan sifat-sifat, menyusun konjektur kemudian mengujinya tetapi hanya menerima apa yang diberikan oleh guru atau siswa hanya menerima apa yang dikatakan oleh guru. Sejalan dengan pendapat Turmudi (2008) yang menyatakan bahwa strategi pembelajaran yang bersifat menekankan kepada hafalan (drill) atau rote learning serta mengutamakan kepada routine computation atau algebraic procedural hendaknya sudah harus dikurangi dan diganti dengan cara menekankan kepada pemahaman.

Salah satu pokok bahasan matematika yaitu tentang geometri. Pengenalan geometri sebagai kemampuan dasar dalam matematika telah cukup lama mendapat penekanan dalam kurikulum SD akhir-akhir ini. Pada realitanya geometri sangat terkait erat dengan kehidupan manusia sehari-hari. Terdapat dua aspek, praktis dan keindahan (estetika) yang dapat ditemukan dalam bidang seni dan arsitektur, eksplorasi ruang (interior), perencanaan perumahan, perencanaan bangunan atau gedung, desain pakaian (mode), dan desain mobil. Topik-topik yang demikian sebenarnya dapat menarik minat siswa dan juga dapat digunakan untuk mengembangkan pengetahuan geometri dan keterampilan siswa, kemampuan tilikan ruang dan kemampuan pemecahan masalah (Turmudi, 2009).

Pada faktanya, masih terdapat siswa yang memiliki konsep geometri yang kurang benar. Hasil penelitian Sulistyowati (2013) tentang analisis kesalahan mengerjakan soal geometri pada siswa kelas V SD menunjukkan bahwa kesalahan yang paling banyak dilakukan siswa adalah kesalahan tipe-1, yaitu kesalahan konsep, termasuk di dalamnya kesalahan dalam memahami soal.

Hasil penelitian Martin \& Structchhens (Van de Walle, 2007, hlm. 150) menunjukkan perbaikan yang terus menerus dan berkesinambungan dalam logika geometri siswa di ketiga tingkat yang telah diuji, 4, 8 dan 12. Lebih lanjut Van de Walle menyatakan bahwa pengalaman akan hubungan bentuk dan ruang ketika dilatih secara konsisten dapat mengembangkan pemahaman ruang. Tanpa pengalaman akan geometri, kebanyakan orang tidak berkembang dalam pemahaman dan logika ruang.

Berdasarkan masalah yang dipaparkan di atas, maka diperlukan proses pembelajaran yang dapat mengembangkan kemampuan pemahaman konsep dan penalaran matematis siswa dalam pokok bahasan geometri. Salah satu caranya adalah dengan pembelajaran kooperatif (cooperative learning). Slavin (2009) menyatakan bahwa pembelajaran kooperatif adalah suatu model pembelajaran dimana siswa belajar dan bekerja sama dalam kelompok-kelompok kecil secara kolaboratif yang anggotanya terdiri dari 4 (empat) sampai 6 (enam) orang, dengan struktur kelompok yang bersifat heterogen. Pembelajaran kooperatif merupakan pembelajaran yang mengutamakan kerja sama dalam menyelesaikan permasalahan untuk menerapkan pengetahuan dan keterampilan dalam rangka mencapai tujuan pembelajaran. Tujuan yang ingin dicapai tidak hanya kemampuan akademik dalam pengertian penguasaan bahan pelajaran, tetapi adanya unsur kerjasama untuk penguasaan materi tersebut. Melalui pembelajaran kooperatif, siswa memiliki kesempatan untuk mempelajari konsep matematika yang sulit dengan bekerjasama dalam kelompoknya.

Salah satu pembelajaran kooperatif yang dapat digunakan adalah tipe Teams Games Tournament (TGT). Dalam TGT, siswa melakukan games dan turnamen dengan anggota-anggota tim lain untuk memperoleh tambahan poin pada skor tim mereka. Turnamen disusun dari pertanyaan-pertanyaan yang relevan 
dengan pelajaran yang dirancang untuk mengetes pengetahuan yang diperoleh siswa dari penyampaian pembelajaran di kelas dan kegiatan-kegiatan kelompok. Selain itu, dalam pembelajaran kooperatif tipe TGT ini sistem penilaian dilakukan terhadap kelompok dengan memberikan reward (penghargaan) di akhir pembelajaran, jika kelompok tersebut mampu menunjukkan prestasi yang dipersyaratkan. Dengan demikian, setiap anggota kelompok akan mempunyai ketergantungan yang positif. Ketergantungan inilah yang selanjutnya akan memunculkan tanggung jawab individu terhadap kelompok. Setiap individu akan saling membantu, mereka akan termotivasi untuk keberhasilan kelompoknya. Sehingga setiap individu akan memiliki kesempatan yang sama untuk memberikan kontribusi demi keberhasilan kelompoknya (Sanjaya, 2006, hlm. 240-241).

Dalam pembelajaran kooperatif tipe TGT terdapat beberapa tahapan. Tahap pertama, yaitu penyajian materi. Pada tahap ini guru menyampaikan materi pelajaran dan memotivasi siswa serta menyampaikan tujuan pembelajaran kepada siswa. Tahap kedua, kegiatan kelompok. Pada tahap ini siswa mengerjakan LKS secara berkelompok. Tahap ketiga, siswa melakukan games (permainan). Pertanyaan dalam game disusun dan dirancang dari materi yang relevan dengan materi yang telah disajikan oleh guru. Tahap keempat, siswa melakukan turnamen. Pada tahap ini siswa akan bermain di dalam meja turnamen. Turnamen adalah susunan beberapa game yang dipertandingkan. Biasanya turnamen dilakukan pada akhir minggu setelah guru melakukan presentasi dan kelompok sudah mengerjakan lembar kerja. Tahap kelima adalah pemberian reward (penghargaan). Pada tahap ini guru memberikan penghargaan kepada kelompok-kelompok yang memenuhi kriteria tertentu (Slavin, 2009).
Berdasarkan latar belakang tersebut, peneliti mencoba untuk meneliti masalah yang berkaitan dengan menumbuhkan pemahaman konsep dan penalaran matematis siswa melalui pembelajaran matematika yang menyenangkan yaitu dengan pembelajaran kooperatif tipe TGT berbantuan media game online matematika di kelas V SDN Ganeas I Kecamatan Talaga Kabupaten Majalengka.

Dalam pembelajaran kooperatif tipe TGT biasanya permainan disusun dari pertanyaan-pertanyaan yang relevan dengan pelajaran yang disusun dalam sebuah kartu. Pada penelitian ini, selain menggunakan kartu, peneliti menggunakan pula media game online. Game online yang digunakan dalam penelitian ini adalah game online matematika yang dapat diakses pada situs http://illuminations.nctm.org. Game online yang digunakan adalah materi tentang jaring-jaring kubus (cube nets) serta volume balok dan kubus (cubes).

\section{TINJAUAN TEORETIS}

\section{Kemampuan Pemahaman Konsep Matematis}

Matematika sebagai sarana pembentukan pola pikir siswa dapat diukur dari kompetensi umum atau kecakapannya

(Mathematical Proficiency). Kilpatrick, Swafford, dan Findell (2001, hlm 5) merumuskan 5 kompetensi umum matematika yaitu pemahaman konsep (conceptual understanding), kemahiran prosedural (procedural fluency), kompetensi strategis (strategic competence), penalaran adaptif (adaptive reasoning) dan berkarakter produktif (productive disposition).

Setiap kompetensi umum di atas bukan merupakan domain yang terpisahpisah, namun kelimanya merupakan jalinan interaksi kecakapan yang saling memperkokoh bangunan pengetahuan, keterampilan, kemampuan dan pandangan 
(beliefs) seseorang (Kilpatrick, Swafford, dan Findell, 2001, hlm 116).

Pemahaman konsep matematis berkenaan dengan memahami ide-ide matematika yang menyeluruh dan fungsional (Kilpatrick, Swafford, dan Findell, 2001, hlm 118). Siswa yang memiliki pemahaman konsep lebih mengetahui fakta dan metode yang terpisah. Mereka mengerti mengapa ideide matematika penting dan macammacam hubungan kalimat yang berguna. Dengan kata lain pemahaman konsep matematis adalah kemampuan dalam memahami konsep, operasi dan relasi dalam matematika.

Adapun indikator pemahaman konsep matematis mencakup namun tidak terbatas pada kemampuan siswa dalam:

1. menyatakan ulang konsep yang telah dipelajari,

2. mengklasifikasikan objekobjek berdasarkan konsep matematika,

3. menerapkan konsep secara algoritma, memberikan contoh atau kontra contoh dari konsep yang dipelajari,

4. menyajikan konsep dalam berbagai bentuk representasi,

5. mengaitkan berbagai konsep matematika secara internal atau eksternal,

6. mengembangkan syarat perlu dan/atau syarat cukup suatu konsep.

Skemp (1976) menyatakan adanya dua jenis pemahaman yaitu pemahaman instrumental dan pemahaman relasional. Pemahaman instrumental diartikan sebagai pemahaman atas konsep yang saling terpisah dan hanya hafal rumus serta dalam menerapkanya tanpa diketahui alasan-alasan ataupun penjelasanya. Sebaliknya pada pemahaman relasional termuat suatu skema atau struktur pengetahuan yang kompleks dan saling berrelasi atau berhubungan yang dapat digunakan pada penyelesaian masalah yang lebih luas dan kompleks.

\section{Kemampuan Penalaran Matematis}

National Council of Teacher Mathematic (NCTM, 2000) menetapkan ada 5 (lima) keterampilan proses yang harus dikuasai siswa melalui pembelajaran matematika, yaitu : (1) pemecahan masalah (problem solving); (2) penalaran dan pembuktian (reasoning and proof); (3) koneksi (connection); (4) komunikasi (communication); serta (5) representasi (representation). Kemampuan bernalar merupakan salah satu dari sekian banyak kecerdasan yang sangat penting dipunyai dan dikuasai siswa terlebih saat mempelajari matematika. Hal ini karena kemampuan inilah yang terutama digunakan anak sewaktu dihadapkan pada masalah matematik yang mesti diselesaikannya. Sejalan dengan itu, Kilpatrick, Swafford, dan Findell (2001) menjelaskan penalaran adaptif merupakan satu dari lima komponen yang membentuk jalinan kemahiran bermatematika.

Menurut Santrock (2010, hlm. 357) penalaran adalah pemikiran logis yang menggunakan logika induksi dan deduksi untuk menghasilkan kesimpulan. Keraf (Shadiq, 2004) menjelaskan penalaran sebagai: "Proses berpikir yang berusaha menghubung-hubungkan faktafakta atau evidensi-evidensi yang diketahui menuju kepada suatu kesimpulan". Sedangkan Copi (Shadiq, 2004) menyatakan bahwa "Reasoning is a special kind of thinking in which inference takes place, in which conclusions are drawn from premises." Berdasarkan definisi yang disampaikan Copi tersebut, Shadiq menerjemahkan bahwa penalaran merupakan kegiatan, proses atau aktivitas berpikir untuk menarik suatu kesimpulan atau membuat suatu pernyataan baru berdasarkan pada beberapa pernyataan yang diketahui benar ataupun yang dianggap benar yang disebut premis. 
Penalaran merupakan tahapan berpikir matematika tingkat tinggi, mencakup kapasitas untuk berpikir secara logis dan sistematis. Terdapat dua jenis penalaran matematika. yaitu penalaran induktif dan penalaran deduktif. Penalaran induktif merupakan suatu kegiatan, suatu proses atau suatu aktivitas berpikir untuk menarik suatu kesimpulan atau membuat suatu pernyataan baru yang bersifat umum (general) berdasarkan pada beberapa pernyataan khusus yang diketahui benar. Sedangkan Deduksi didefinisikan sebagai proses penalaran yang menerapkan hal-hal yang umum terlebih dahulu untuk seterusnya dihubungkan dalam bagianbagian yang khusus. Pada penalaran deduktif proses penalaran konklusinya diturunkan secara mutlak dari premispremisnya.

Menurut NCTM (2000, hlm. 56), bernalar matematik adalah suatu kebiasaan, dan seperti kebiasaan lainnya, maka ia mesti dikembangkan melalui pemakaian yang konsisten dan dalam berbagai konteks. NCTM menambahkan, orang yang bemalar dan berpikir secara analitik akan cenderung mengenal pola, struktur, atau keberaturan baik di dunia nyata maupun pada simbol-simbol.

Siswa dikatakan mampu melakukan penalaran matematika bila ia mampu menggunakan penalaran pada pola dan sifat, melakukan manipulasi matematika dalam membuat generalisasi, menyusun bukti, atau menjelaskan gagasan dan pernyataan matematika. Dalam kaitan ini, pada penjelasan teknis Peraturan Dirjen Dikdasmen Depdiknas Nomor 506/C/Kep/PP/2004 tanggal 11 November 2004 tentang rapor diuraikan bahwa indikator siswa yang memiliki kemampuan dalam penalaran matematika adalah:

1. Mengajukan dugaan.

2. Melakukan manipulasi matematika.
3. Menarik kesimpulan, menyusun bukti, memberikan alasan atau bukti terhadap kebenaran solusi.

4. Menarik kesimpulan dari pernyataan.

5. Memeriksa kesahihan suatu argumen.

6. Menemukan pola atau sifat dari gejala matematis untuk membuat generalisasi.

\section{Model Pembelajaran Kooperatif tipe TGT (Teams-Games-Tournaments)}

Slavin (2009) menyatakan bahwa pembelajaran kooperatif adalah suatu model pembelajaran dimana siswa belajar dan bekerja sama dalam kelompokkelompok kecil secara kolaboratif yang anggotanya terdiri dari 4 (empat) sampai 6 (enam) orang, dengan struktur kelompok yang bersifat heterogen. Sejalan dengan pendapat Lie (2008, hlm. 41) yang menyatakan bahwa pembelajaran kooperatif merupakan model pembelajaran dengan menggunakan sistem pengelompokkan secara heterogen, yaitu tiga sampai lima siswa yang memiliki kemampuan akademik, jenis kelamin, suku yang berbeda-beda dan saling bekerja sama untuk mencapai tujuan pembelajaran yang dirumuskan. Selanjutnya dikatakan pula, keberhasilan belajar dari kelompok tergantung pada kemampuan dan aktivitas anggota kelompok, baik secara individual maupun secara kelompok.

Dalam pembelajaran kooperatif terdapat beberapa variasi model yang dapat diterapkan yaitu diantaranya: Student Team Achievement Divisoin (STAD), Jigsaw, Teams Games Tournaments (TGT), Group Investigation (GI), Rotating Trio Exchange, dan Group Resume. TGT adalah salah satu tipe pembelajaran kooperatif yang menempatkan siswa dalam kelompokkelompok belajar yang beranggotakan 4 sampai 6 orang siswa yang memiliki kemampuan, jenis kelamin dan suku atau 
ras yang berbeda. Dengan adanya heterogenitas anggota kelompok, diharapkan dapat memotivasi siswa untuk saling membantu antar siswa yang berkemampuan lebih dengan siswa yang berkemampuan kurang dalam menguasai materi pelajaran. Huda (2011, hlm. 117) berpendapat bahwa teknis pelaksanaan TGT mirip dengan STAD. Setiap siswa ditempatkan dalam satu kelompok yang terdiri dari 3 orang yang berkemampuan rendah, sedang, dan tinggi. Dengan demikian, masing-masing kelompok memiliki komposisi anggota yang comparable.

Pembelajaran kooperatif tipe TGT pada mulanya dikembangkan oleh David De Vries dan Keith Edwards, ini merupakan metode pembelajaran pertama dari John Hopkins (Slavin, 2009, hlm. 13). Menurut Slavin (2009, hlm. 166-167) TGT terdiri dari 5 langkah tahapan yaitu: tahap penyajian kelas (class precentation), belajar dalam kelompok (teams), permainan (games), pertandingan (tournament), dan perhargaan kelompok (team recognition).

$$
\text { Penyajian kelas dalam }
$$

pembelajaran kooperatif tipe TGT tidak berbeda dengan pengajaran biasa atau pengajaran klasikal oleh guru. Guru menyampaikan materi kepada siswa terlebih dahulu. Selain menyajikan materi, pada tahap ini guru juga menyampaikan tujuan, tugas atau kegiatan yang harus dilakukan siswa, serta memberikan motivasi. Ketika penyajian kelas berlangsung siswa sudah berada dalam kelompoknya. Dengan demikian mereka akan memperhatikan dengan serius selama pengajaran penyajian kelas berlangsung sebab setelah ini mereka harus mengerjakan games akademik dengan sebaik-baiknya karena skor mereka akan menentukan skor kelompok mereka. Selain itu, siswa dituntut berpartisipasi aktif dalam pembelajaran seperti mengajukan pertanyaan, menjawab pertanyaan, dan mempresentasikan di depan kelas.

Setelah penyajian materi oleh guru, siswa akan belajar dalam kelompok. Kelompok disusun dengan beranggotakan 4-6 orang yang mewakili pencampuran dari berbagai keragaman dalam kelas seperti kemampuan akademik, jenis kelamin, rasa atau etnik. Fungsi utama mereka dikelompokkan adalah anggotaanggota kelompok saling meyakinkan bahwa mereka dapat bekerja sama dalam belajar dan mengerjakan game atau lembar kerja dan lebih khusus lagi untuk menyiapkan semua anggota dalam menghadapi turnamen. Dalam kelompoknya siswa berusaha mendalami materi yang telah diberikan guru. Setiap siswa mempunyai tanggung jawab untuk memastikan bahwa teman satu tim mereka telah mempelajari dan menguasai materinya.

Tugas siswa selanjutnya adalah melakukan game. Pertanyaan dalam game disusun dan dirancang dari materi yang relevan dengan materi yang telah disajikan untuk menguji pengetahuan yang diperoleh mewakili masing-masing kelompok. Sebagian besar pertanyaan pada kuis adalah bentuk sederhana. Setiap siswa mengambil sebuah kartu yang diberi nomor dan menjawab pertanyaan yang sesuai dengan nomor pada kartu tersebut. Pada penelitian ini, game yang digunakan adalah game online yang diikuti oleh perwakilan kelompok.

Turnamen adalah susunan beberapa game yang dipertandingkan. Biasanya turnamen dilakukan pada akhir minggu atau pada setiap unit setelah guru melakukan persentasi kelas dan kelompok sudah mengerjakan lembar kerja. Permainan yang dikemas dalam bentuk turnamen ini dapat berperan sebagai penilaian alternatif atau dapat pula sebagai review materi pembelajaran (Rusman, 2011, hlm. 224).

Rekognisi tim (penghargaan kelompok) dilakukan dengan memberi 
penghargaan berupa hadiah atau sertifikat atas usaha yang telah dilakukan kelompok selama belajar sehingga mencapai kriteria yang telah disepakati bersama. Penghargaan diberikan kepada kelompok yang mendapat skor tertinggi.

\section{Game online dalam Pembelajaran Matematika}

Pertama kalinya game online hadir pada tahun 1960 dimana komputer digunakan untuk bermain game hanya untuk 2 orang saja dalam ruangan yang sama. Namun pada tahun 1970 muncullah jaringan komputer berbasis paket yang tidak hanya sebatas LAN (Local Area Network) saja tetapi sudah mencakup WAN (Wide Area Network) dan menjadi internet dimana kemampuannya lebih sehingga pemain bisa memainkan game tersebut lebih banyak dan tidak harus berada di suatu ruangan yang sama. Game online sendiri mulai muncul di Indonesia pada bulan maret 2001. Yang pertama kali diperkenalkan adalah permainan game online yang masih sangat sederhana yakni Nexian online. Game online yang beredar di Indonesia cukup beragam mulai aksi, olah raga, dan RPG (role playing game) sehingga tercatat lebih dari 20 judul game online yang beredar di Indonesia.

Banyak penelitian telah dilakukan mengenai penggunaan game dalam pembelajaran. Hasil penelitian menunjukkan bahwa siswa memiliki pendapat yang positif terhadap game dan game adalah media pembelajaran yang efektif (Katmada, dkk, 2014, hlm 230). Terdapat pengaruh yang signifikan antara game online terhadap tingkat efektivitas komunikasi interpersonal pada kalangan pelajar kelas 5 SD (Affandi, 2013, hlm 177). Siswa menjadi lebih mandiri dan partisipasi siswa di kelas meningkat (Akpan \& Beard, 2014, hlm 222). Aktivitas belajar siswa meningkat (Dourda, dkk, 2014).

Penelitian mengenai penggunaan game dalam pembelajaran matematika dilakukan oleh Susan Main dan John O'Rourke (2011, hlm 52). Penelitian mereka bertujuan untuk membandingkan penggunaan media game dengan metode mengajar tradisional. Hasil penelitian menunjukkan bahwa penggunaan media game online dalam pembelajaran matematika membuat siswa antusias dalam belajar, meningkatkan hasil belajar dan siswa mendukung satu sama lain.

Patahuddin \& Rokhim (2009, hlm 110) dalam artikelnya yang berjudul "Website Permainan Matematika Online untuk Belajar Matematika secara Menyenangkan" menyatakan bahwa hasil analisis mereka terhadap sejumlah website-website matematika menunjukkan bahwa terdapat website permainan matematika yang dapat digunakan untuk membangun pemahaman konsep, mengembangkan berpikir kritis, serta melatihkan kecepatan berhitung (drilling). Menyadari potensi internet yang sangat besar dalam membantu siswa belajar matematika dengan cara menyenangkan melalui permainan, Patahuddin \& Rokhim menyarankan untuk mengujicobakan website-website tersebut dalam sebuah penelitian.

\section{METODOLOGI PENELITIAN}

Penelitian dilaksanakan dengan menggunakan metode kuasi eksperimen. Pada metode kuasi eksperimen ini subyek yang akan diteliti merupakan subyek yang telah terdaftar dalam kelasnya. Jadi, tidak dilakukan lagi pengelompokkan secara acak. Creswell (2012) mengatakan bahwa penelitian kuasi eksperimen tidak menetapkan subyek penelitian secara acak ke dalam kelompok. Dalam penelitian ini, peneliti menggunakan kelompok atau kelas yang sudah ada.

Desain yang digunakan dalam penelitian ini adalah desain pretestposttets control group design. Dalam desain ini terdapat dua kelompok yang dipilih sebagai kelompok eksperimen dan kelompok kontrol, yang keduanya 
dilakukan pretes dan postes. Kelompok eksperimen akan memperoleh perlakuan pembelajaran kooperatif tipe TGT berbantuan media game online dan kelompok kontrol akan mendapatkan pembelajaran langsung.

Penelitian ini dilaksanakan di SDN

Ganeas I dan SDN Talagakulon I Kecamatan Talaga Kabupaten Majalengka. Subjek dalam penelitian ini adalah siswa kelas V SDN Ganeas I sebagai kelompok eksperimen dan siswa kelas V SDN Talagakulon I sebagai kelompok kontrol. Peneliti memilih kedua sekolah tersebut karena memiliki kesamaan karakteristik, yaitu status sekolahnya negeri dan rata-rata hasil belajarnya relatif sama.

Setelah pelaksanaan penelitian, diperoleh data untuk diolah dan dianalisis. Data yang diperoleh yaitu hasil pretes dan postes kemampuan pemahaman konsep dan penalaran matematis siswa. Data yang telah terkumpul selanjutnya akan diolah. Pengolahan data pada penelitian ini menggunakan bantuan software komputer yaitu Statistical Product and Service Solution (SPSS) version 21.0 for windows. Untuk menguji hipotesis, data-data tersebut diolah secara statistik dengan langkah-langkah sebagai berikut: 1) Menghitung $\mathrm{N}$-gain ternormalisasi. Perhitungan ini bertujuan untuk mengetahui peningkatan nilai pretest dan posttest dari kedua kelas. 2) Menguji normalitas. Uji normalitas dilakukan untuk menentukan apakah sebaran data berdistribusi normal atau tidak. 3) Menguji homogenitas varians. Uji homogenitas varians untuk mengetahui apakah varians kedua kelompok sama atau berbeda. 4) Uji hipotesis menggunakan uji perbedaan dua rata-rata (Uji-t) jika data yang diperoleh berdistribusi normal, dan jika data tidak berdistribusi normal, pengujian hipotesis menggunakan uji statistik nonparametrik yaitu uji MannWhitney.

\section{HASIL PENELITIAN}

Kemampuan Pemahaman Konsep dan Penalaran Matematis Sebelum Pembelajaran

Dari perolehan nilai rata-rata hasil pretes secara umum dapat dikatakan bahwa rata-rata nilai hasil pretes kemampuan pemahaman konsep dan penalaran matematis pada kedua kelompok tidak jauh berbeda. Hal ini dapat terlihat dari perolehan mean (ratarata) skor pretes kemampuan pemahaman konsep kelompok eksperimen sebesar 15,11 sedangkan rata-rata skor pretes kelompok kontrol sebesar 18,05. Secara matematis, rata-rata pretes kedua kelas berbeda, dengan perbedaannya sebesar 2,94. Begitupun dengan rata-rata skor pretes kemampuan penalaran matematis kelompok eksperimen sebesar 4,94 sedangkan rata-rata skor pretes penalaran matematis kelompok kontrol sebesar 6,47. Secara matematis, rata-rata pretes kedua kelas berbeda, dengan perbedaannya sebesar 1,53.

Berdasarkan hasil perhitungan dengan uji statistik melalui program SPSS versi 21 for windows diketahui bahwa hasil pretes kemampuan pemahaman konsep dan penalaran matematis siswa kelompok eksperimen dan kelompok kontrol berdistribusi normal dan juga homogen. Karena data hasil pretes pemahaman konsep dan penalaran matematis pada kelompok eksperimen dan kontrol berdistribusi normal dan memiliki varians yang homogen, maka uji perbedaan yang dilakukan adalah uji statistik parametrik melalui uji Independent sample T Test (uji t).

Dari hasil perhitungan uji perbedaan skor pretes pemahaman diperoleh nilai $\mathrm{t}$ hitung $=-1,799$ dengan angka signifikansi $0,081>0,05$, maka $\mathrm{H}_{0}$ diterima. Artinya bahwa tidak terdapat perbedaan kemampuan pemahaman konsep matematis antara kelompok eksperimen dan kelompok kontrol. 
Berdasarkan hasil perhitungan uji perbedaan skor pretes penalaran matematis diperoleh Sig. perbedaan dua rata-rata adalah dari Sig.(2-tailed) yaitu $0,207>0,05$, maka $\mathrm{H}_{0}$ diterima. Artinya bahwa tidak terdapat perbedaan kemampuan penalaran matematis antara kelompok eksperimen dan kelompok kontrol.

\section{Kemampuan Pemahaman Konsep dan Penalaran Matematis Setelah pembelajaran}

Pada tahap analisis data pretes diperoleh bahwa kemampuan awal pemahaman konsep dan penalaran matematis siswa antara kelompok eksperimen dan kelompok kontrol adalah sama. Postes dilakukan untuk melihat tingkat pemahaman konsep matematis siswa setelah pembelajaran berlangsung.

Dari perolehan nilai rata-rata hasil postes secara umum dapat dikatakan bahwa rata-rata nilai hasil postes kemampuan pemahaman konsep dan penalaran matematis pada kedua kelompok tidak jauh berbeda. Hal ini dapat terlihat dari perolehan mean (ratarata) skor postes kemampuan pemahaman konsep kelompok eksperimen sebesar 25,33 sedangkan mean (rata-rata) skor postes kelompok kontrol sebesar 22,32. Secara matematis, rata-rata postes kedua kelas berbeda, dengan perbedaannya sebesar 3,01. Begitupun dengan rata-rata skor postes kemampuan penalaran matematis kelompok eksperimen sebesar 10,61 sedangkan mean (rata-rata) skor postes penalaran matematis kelompok kontrol sebesar 8,63. Secara matematis, rata-rata postes kedua kelas berbeda, dengan perbedaannya sebesar 1,98 .

Berdasarkan hasil perhitungan dengan uji statistik melalui program SPSS versi 21 for windows diketahui bahwa hasil postes kemampuan pemahaman konsep dan penalaran matematis siswa kelompok eksperimen dan kelompok kontrol tidak berdistribusi normal. Karena data hasil postes pemahaman konsep dan penalaran matematis pada kelompok eksperimen dan kontrol tidak berdistribusi normal, maka uji perbedaan yang dilakukan adalah uji statistik nonparametrik melalui uji Mann-Whitney.

Dari hasil perhitungan uji perbedaan skor postes pemahaman diketahui nilai Sig.(2-tailed) yaitu 0,077 > 0,05 , maka $\mathrm{H}_{0}$ diterima. Artinya bahwa tidak terdapat perbedaan kemampuan pemahaman konsep matematis antara kelompok eksperimen dan kelompok kontrol. Jadi dapat disimpulkan bahwa kemampuan akhir pemahaman konsep matematis siswa antara kelompok eksperimen dan kelompok kontrol adalah tidak berbeda secara signifikan.

Berdasarkan hasil perhitungan uji perbedaan skor postes penalaran matematis diketahui nilai Sig.(2-tailed) yaitu $0,211>0,05$, maka $\mathrm{H}_{0}$ diterima. Artinya bahwa tidak terdapat perbedaan kemampuan penalaran matematis antara kelompok eksperimen dan kelompok kontrol. Jadi dapat disimpulkan bahwa tidak terdapat perbedaan kemampuan akhir penalaran matematis siswa antara kelompok eksperimen dan kelompok kontrol.

\section{Analisis Gain Kemampuan Pemahaman Konsep dan Penalaran Matematis}

Analisis peningkatan kemampuan pemahaman konsep dan penalaran matematis antara kelompok eksperimen dan kelompok kontrol dilakukan dengan analisis data $\mathrm{N}$-gain. Berdasarkan perhitungan, diperoleh mean (rata-rata) $\mathrm{N}$ gain kelompok eksperimen sebesar 0,8967 sedangkan mean (rata-rata) $\mathrm{N}$-gain kelompok kontrol sebesar 0,6332. Maka menurut kriteria N-gain, kualitas kemampuan pemahaman konsep matematis siswa kelompok eksperimen maupun kelompok kontrol berada pada level sedang. Secara matematis, N-gain 
kedua kelompok berbeda, perbedaannya adalah 0,2635.

Berdasarkan perhitungan diperoleh mean (rata-rata) N-gain penalaran matematis kelompok eksperimen sebesar 0,7594 sedangkan berbeda secara signifikan atau tidak maka harus dilakukan uji statistik.

Berdasarkan hasil perhitungan dengan uji statistik melalui program SPSS versi 21 for windows diketahui bahwa Ngain kemampuan pemahaman konsep

Tabel 1.1

Hasil Uji Mann-Whitney N-gain Pemahaman Konsep Matematis

\begin{tabular}{|l|r|}
\hline & N-gain Pemahaman \\
\hline Mann-Whitney U & 111.000 \\
Wilcoxon W & 301.000 \\
Z & -2.017 \\
Asymp. Sig. (2-tailed) & .044 \\
Exact Sig. [2*(1-tailed Sig.)] & $.070^{\mathrm{b}}$ \\
\hline
\end{tabular}

mean (rata-rata) $\mathrm{N}$-gain penalaran matematis kelompok kontrol sebesar 0,3695. Menurut kriteria N-gain kualitas kemampuan penalaran matematis siswa kelompok eksperimen berada pada level tinggi sedangkan kelompok kontrol berada pada level sedang. Secara matematis, rata-rata gain kedua kelas berbeda, dengan perbedaannya sebesar 0,3899 . Untuk mengetahui apakah ratarata skor gain pada kedua kelompok

Dari tabel 1.1 diperoleh $\mathrm{z}$ hitung $=$ 2,017 dengan Sig. perbedaan dua rata-rata dari Sig.(2-tailed) yaitu $0,044<0,05$, maka $\mathrm{H}_{0}$ ditolak. Artinya bahwa terdapat perbedaan peningkatan kemampuan pemahaman konsep matematis antara kelas eksperimen dan kelas kontrol. Jadi dapat disimpulkan bahwa peningkatan kemampuan pemahaman konsep matematis siswa antara kelas eksperimen dan kelas kontrol adalah berbeda secara signifikan.

Berdasarkan hasil perhitungan dengan uji statistik melalui program SPSS versi 21 for windows diketahui bahwa data matematis siswa kelompok eksperimen dan kelompok kontrol tidak berdistribusi normal. Karena data N-gain pemahaman konsep matematis pada kelompok eksperimen dan kontrol tidak berdistribusi normal, maka uji perbedaan yang dilakukan adalah uji statistik nonparametrik melalui uji Mann-Whitney. Hasil uji perbedaan dua rata-rata $\mathrm{N}$-gain pemahaman konsep matematis dengan menggunakan uji Independent Sample T Test adalah sebagai berikut.

$\mathrm{N}$-gain kemampuan penalaran matematis siswa kelompok eksperimen dan kelompok kontrol tidak berdistribusi normal dan juga memiliki varians yang tidak homogen. Karena data N-gain penalaran matematis pada kelompok eksperimen dan kontrol tidak berdistribusi normal dan memiliki memiliki varians yang tidak homogen, maka uji perbedaan yang dilakukan adalah uji statistik nonparametrik malalui uji Mann Whitney. Hasil uji perbedaan dua rata-rata $\mathrm{N}$-gain penalaran matematis dengan menggunakan uji U-Mann Whitney adalah sebagai berikut. 
Dari output hasil uji statistik melalui uji Mann-Whitney pada tabel 4.18 diketahui nilai Sig. (2-tailed) adalah

Tabel 1.2

Hasil Uji Mann-Whitney N-gain Penalaran Matematis

\begin{tabular}{|l|r|}
\hline & \multicolumn{1}{|c|}{ nilaigainpenalaran } \\
\hline Mann-Whitney U & 87.000 \\
Wilcoxon W & 277.000 \\
Z & -2.605 \\
Asymp. Sig. (2-tailed) & .009 \\
Exact Sig. [2*(1-tailed Sig.)] & $.010^{\mathrm{b}}$ \\
\hline
\end{tabular}

0,009. Dikarenakan nilai Sig. $(2$-tailed $)=$ $0,009<0,05$, dengan demikian $\mathrm{H}_{0}$ ditolak dan $\mathrm{H}_{1}$ diterima. Artinya, hipotesis yang menyatakan terdapat perbedaan peningkatan kemampuan penalaran matematis siswa yang belajar dengan pembelajaran kooperatif tipe TGT berbantuan media game online dengan siswa yang belajar dengan pembelajaran langsung (direct instruction) diterima.

\section{PEMBAHASAN}

\section{Peningkatan Kemampuan Pemahaman Konsep Matematis}

Berdasarkan pengolahan data hasil penelitian yang telah diuraikan pada bagian sebelumnya, menunjukkan bahwa terdapat peningkatan kemampuan pemahaman konsep matematis pada siswa yang memperoleh pembelajaran kooperatif tipe Teams Games Tournament (TGT) berbantuan media game online secara signifikan lebih tinggi daripada siswa yang memperoleh pembelajaran langsung (direct instruction). Dengan demikian dapat dikatakan bahwa pembelajaran kooperatif tipe Teams Games Tournament (TGT) berbantuan media game online memberikan pengaruh positif secara signifikan terhadap peningkatan kemampuan pemahaman konsep matematis siswa. pengaruh ini berada pada taraf keyakinan $95 \%$ atau pada $\alpha<0,05$ yang artinya peluang tidak terjadinya tidak terdapat pengaruh yang siginifikan sangat kecil yaitu dibawah 0,05 . Hal ini sesuai pendapat Furqon (2012, hlm. 170) yang menyatakan bahwa tingkat keyakinan atau $\alpha$ menunjukkan peluang munculnya nilai sampel jika hipotesis nol itu benar.

Perbedaan peningkatan kemampuan pemahaman konsep matematis antara kelas eksperimen yang mendapat pembelajaran kooperatif tipe Teams Games Tournament (TGT) berbantuan media game online dengan siswa yang mendapatkan pembelajaran langsung dapat dilihat dari skor pretes dan postes kemampuan pemahaman konsep matematis. Pada kelas eksperimen ratarata skor pretes lebih kecil daripada kelas kontrol yaitu 15,11 dan 18,05. Akan tetapi hasil uji perbedaan skor pretes kedua kelas menggunakan uji $\mathrm{t}$ disimpulkan bahwa tidak terdapat perbedaan kemampuan pemahaman konsep matematis antara kelas eksperimen dan kelas kontrol. Hal ini berarti walaupun rata-rata skor pretes berbeda antara kelas eksperimen dan kelas kontrol, namun dianggap sama atau sederajat. Dengan kata lain kemampuan awal pemahaman konsep matematis siswa antara kelas eksperimen dan kelas kontrol tidak ada perbedaan yang berarti.

Dari hasil postes diketahui bahwa rata-rata skor postes kelas eksperimen lebih tinggi daripada rata-rata skor postes kelas kontrol yaitu 25,33 dan 22,32. Hasil uji perbedaan rata-rata kemampuan akhir (pencapaian) kedua kelas menggunakan uji Mann-Whitney disimpulkan bahwa tidak terdapat perbedaan kemampuan pemahaman konsep matematis antara kelas eksperimen dan kelas kontrol. 
Sebelum melakukan penarikan kesimpulan, dilakukan uji perbedaan ratarata N-gain menggunakan uji MannWhitney untuk mengetahui apakah terdapat perbedaan peningkatan kemampuan pemahaman konsep matematis siswa pada kelas eksperimen dan kelas kontrol. Berdasarkan hasil pengujian, disimpulkan bahwa peningkatan kemampuan pemahaman konsep matematis siswa kelas eksperimen berbeda dengan kemampuan pemahaman konsep matematis siswa kelas kontrol. Mean (rata-rata) N-gain kelas eksperimen sebesar 0,8967 sedangkan mean (ratarata) $\mathrm{N}$-gain kelas kontrol sebesar 0,6332. Hasil interperetasi $\mathrm{N}$-gain menunjukkan bahwa peningkatan kemampuan pemahaman konsep matematis kelas eksperimen tergolong tinggi sedangkan kelas kontrol tergolong sedang.

Berdasarkan hasil pretes yang didukung oleh uji perbedaan rata-rata pretes pada kelas eksperimen dan kontrol, menunjukan bahwa tidak terdapat perbedaan pada kemampuan awal pemahaman konsep matematis kedua kelas. Mean (rata-rata) kelas kontrol lebih tinggi daripada kelas eksperimen, nilai pretes yang diperoleh siswa menunjukan kemampuan awal yang bisa saja diperoleh dari pengalaman belajar sebelumnya. Tetapi setelah dilakukan proses pembelajaran dengan menggunakan model pembelajaran kooperatif tipe TGT berbantuan media game online, nilai ratarata kemampuan pemahaman konsep matematis pada kelas eksperimen lebih tinggi, dengan melakukan uji MannWhitney untuk mengetahui perbedaan rata-rata, dinyatakan bahwa terdapat perbedaan yang signifikan dalam kemampuan pemahaman konsep matematis pada kelas eksperimen dan kontrol. Dari kemampuan awal dan akhir itu diketahui bahwa dengan menggunakan pembelajaran kooperatif tipe TGT berbantuan media game online siswa pada kelas eksperimen berhasil menyetarakan kemampuannya dengan kelas kontrol yang mempunyai kemampuan awal pemahaman konsep matematis lebih tinggi. Hal ini berarti bahwa pembelajaran kooperatif tipe TGT berbantuan media game online mempunyai arti penting dalam peningkatan kemampuan pemahaman konsep matematis siswa.

Hasil uji perbedaan rata-rata peningkatan pemahaman konsep matematis dengan menggunakan uji Mann-Whitney dan mengambil taraf signifikan $\alpha=0,05$, dinyatakan bahwa peningkatan pemahaman konsep matematis siswa pada kelas eksperimen dan kelas kontrol berbeda secara signifikan, karena rata-rata pada kelas eksperimen lebih besar daripada kelas kontrol maka dapat dikatakan bahwa pembelajaran kooperatif tipe TGT berbantuan media game online dapat menghasilkan peningkatan pemahaman konsep matematis yang lebih tinggi dibandingkan dengan pembelajaran langsung.

Hasil dari penelitian ini menyimpulkan bahwa model pembelajaran kooperatif tipe TGT berbantuan media game online dalam pembelajaran matematika mengindikasikan potensi yang baik untuk meningkatkan pemahaman konsep matematis siswa. Peningkatan kemampuan pemahaman konsep matematis siswa yang memperoleh pembelajaran kooperatif tipe TGT berbantuan media game online ini dikarenakan prosedur pembelajaran kooperatif tipe TGT berbantuan media game online yang menekankan siswa aktif membangun pemahamannya. Melalui pembelajaran kooperatif siswa didorong untuk bekerja sama secara maksimal di dalam kelompoknya. Kerja sama disini dimaksudkan setiap anggota kelompok harus saling membantu. Dalam pelaksanaan pembelajaran, siswa yang berkemampuan lebih tinggi membantu siswa yang berkemampuan lebih rendah 
dalam memahami materi pelajaran, sehingga siswa yang berkemampuan rendah tidak menarik diri ketika pembelajaran dan hasil belajarnya meningkat. Hal ini sejalan dengan hasil penelitian Sari (2012) yang menyatakan bahwa pembelajaran kooperatif tipe TGT dapat meningkatkan keaktifan dan hasil belajar siswa.

\section{Peningkatan Kemampuan Penalaran Matematis}

Berdasarkan pengolahan data hasil penelitian yang telah diuraikan pada bagian sebelumnya, menunjukkan bahwa terdapat peningkatan kemampuan penalaran matematis pada siswa yang memperoleh pembelajaran langsung (direct instruction) secara signifikan lebih tinggi daripada siswa yang memperoleh pembelajaran kooperatif tipe Teams Games Tournament (TGT) berbantuan media game online. Dengan demikian dapat dikatakan bahwa pembelajaran direct instruction memberikan pengaruh positif secara signifikan terhadap peningkatan kemampuan penalaran matematis siswa.

Perbedaan peningkatan

kemampuan penalaran matematis antara kelas eksperimen yang mendapat pembelajaran kooperatif tipe Teams Games Tournament (TGT) berbantuan media game online dengan siswa yang mendapatkan pembelajaran langsung dapat dilihat dari skor pretes dan postes kemampuan penalaran matematis. Pada kelas eksperimen rata-rata skor pretes lebih kecil daripada kelas kontrol yaitu 4,94 dan 6,47. Akan tetapi hasil uji perbedaan dua rata-rata skor pretes kedua kelas menggunakan uji $\mathrm{t}$ disimpulkan bahwa tidak terdapat perbedaan kemampuan penalaran matematis antara kelas eksperimen dan kelas kontrol. Hal ini berarti walaupun rata-rata skor pretes berbeda antara kelas eksperimen dan kelas kontrol, namun dianggap sama atau sederajat. Dengan kata lain kemampuan awal penalaran matematis siswa antara kelas eksperimen dan kelas kontrol tidak ada perbedaan yang berarti.

Untuk mengetahui kemampuan penalaran matematis siswa setelah diberikan tindakan berupa pembelajaran kooperatif tipe Teams Games Tournament (TGT) berbantuan media game online di kelas eksperimen dan tindakan pembelajaran langsung di kelas kontrol, maka dilakukan postes. Hasil rata-rata skor postes kelas eksperimen lebih tinggi daripada rata-rata skor postes kelas kontrol yaitu 10,61 dan 8,63. Hasil uji perbedaan rata-rata kemampuan akhir (pencapaian) kedua kelas menggunakan uji Mann-Whitney disimpulkan bahwa tidak terdapat perbedaan rata-rata postes penalaran matematis antara kelas eksperimen dan kelas kontrol. Dengan kata lain kemampuan akhir penalaran matematis siswa antara kelas eksperimen dan kelas kontrol tidak ada perbedaan yang berarti.

Sebelum melakukan penarikan kesimpulan, dilakukan uji perbedaan ratarata N-gain. Karena skor N-gain penalaran tidak berdistribusi normal, maka dilakukan uji perbedaan rata-rata $\mathrm{N}$-gain menggunakan uji Mann-Whitney untuk mengetahui apakah terdapat perbedaan peningkatan kemampuan penalaran matematis siswa pada kelas eksperimen dan kelas kontrol. Berdasarkan hasil pengujian, disimpulkan bahwa peningkatan kemampuan penalaran matematis siswa kelas eksperimen berbeda dengan kemampuan penalaran matematis siswa kelas kontrol. Mean (rata-rata) $\mathrm{N}$-gain penalaran matematis kelas eksperimen sebesar 0,7594 sedangkan mean (rata-rata) $\mathrm{N}$-gain penalaran matematis kelas kontrol sebesar 0,3695. Hasil interperetasi $\mathrm{N}$-gain menunjukkan bahwa peningkatan kemampuan penalaran matematis kelas eksperimen tergolong tinggi sedangkan kelas kontrol tergolong sedang. 
Hasil uji perbedaan rata-rata peningkatan penalaran matematis dengan menggunakan uji Mann-Whitney dan mengambil taraf signifikan $\alpha=0,05$, dinyatakan bahwa peningkatan penalaran matematis siswa pada kelas eksperimen dan kelas kontrol berbeda secara signifikan, karena rata-rata pada kelas eksperimen lebih besar daripada kelas kontrol maka dapat dikatakan bahwa pembelajaran kooperatif tipe TGT berbantuan media game online dapat meningkatkan penalaran matematis yang lebih tinggi dibandingkan dengan pembelajaran langsung. Hal ini sejalan dengan hasil penelitian Purnamasari (2014) yang menyatakan bahwa peningkatan kemampuan penalaran siswa yang mengikuti pembelajaran kooperatif tipe TGT lebih baik daripada siswa yang mengikuti pembelajaran langsung.

Dari analisis data dan pembahasan di atas menunjukkan bahwa pembelajaran kooperatif tipe TGT berbantuan media game online dapat meningkatkan kemampuan pemahaman konsep dan penalaran matematis siswa pada pokok bahasan bangun ruang. Pada pokok bahasan yang berbeda dengan peneliti, hasil penelitian Setiana dan Purwanto (2013) menunjukkan bahwa pembelajaran kooperatif tipe TGT dapat meningkatkan hasil belajar matematika pada materi penjumlahan pecahan. Demikian pula penelitian Nurdiansyah (2014) yang menunjukkan bahwa pembelajaran kooperatif tipe TGT dapat meningkatkan hasil belajar matematika pada materi pokok operasi bilangan pecahan.

$$
\text { Pada tahap pelaksanaan }
$$

pembelajaran, saat mengajar di kelas kontrol peneliti tidak mengalami kesulitan karena siswa sudah terbiasa mendapatkan pembelajaran langsung (direct instruction) sebelumnya. Tetapi saat pelaksanaan pembelajaran kooperatif tipe TGT berbantuan media game online peneliti mengalami beberapa hambatan, diantaranya, masih terdapat siswa yang pasif dalam pembelajaran. Hal ini disebabkan siswa tersebut dalam keadaan sakit. Selain itu, pada saat melakukan game online, koneksi internet kadang mengalami gangguan. Namun hal ini bisa diatasi segera dengan menggunakan hotspot wifi. Karena pembelajaran kooperatif tipe TGT berbantuan media game online memerlukan waktu yang cukup lama, terkadang waktu yang telah dialokasikan tidak mencukupi, sehingga mengambil waktu dari waktu istirahat atau jam pelajaran lain. Untuk menerapakan pembelajaran kooperatif tipe TGT berbantuan media game online lebih baik lagi, perlu penyusunan alokasi waktu secara seksama untuk setiap topik dan tahapan pembelajaran.

Dalam proses pembelajaran menunjukkan bahwa pembelajaran kooperatif tipe TGT berbantuan media game online dari segi prosedur atau tahapan belajar maupun media yang dipergunakan cenderung berpengaruh baik terhadap peningkatan pemahaman konsep dan penalaran matematis siswa. Disamping itu, tidak ditemukan penolakan dari siswa mengenai prosedur maupun media pembelajaran. Ini mengindikasikan bahwa pembelajaran kooperatif tipe TGT berbantuan media game online cukup layak dijadikan sebagai model pembelajaran matematika di kelas $\mathrm{V}$ sekolah dasar.

\section{KESIMPULAN REKOMENDASI}

DAN

Berdasarkan rumusan masalah dan hasil penelitian serta pembahasan terhadap hasil penelitian sebagaimana yang diuraikan pada bab sebelumnya maka diperoleh kesimpulan dan rekomendasi dari hasil penelitian.

Berdasarkan data penelitian dan hasil analisis data diperoleh beberapa kesimpulan terkait dengan hipotesishipotesis penelitian, antara lain:

1. Tidak terdapat perbedaan kemampuan pemahaman konsep 
matematis siswa yang mendapat pembelajaran kooperatif tipe TGT berbantuan media game online dengan siswa yang mendapatkan pembelajaran langsung.

2. Tidak terdapat perbedaan kemampuan penalaran matematis siswa yang mendapat pembelajaran kooperatif tipe TGT berbantuan media game online dengan siswa yang mendapatkan pembelajaran langsung.

3. Terdapat perbedaan peningkatan kemampuan pemahaman konsep matematis siswa yang mendapatkan pembelajaran kooperatif tipe TGT berbantuan media game online dengan siswa yang mendapatkan pembelajaran langsung.

4. Terdapat perbedaan peningkatan kemampuan penalaran matematis siswa yang mendapatkan pembelajaran kooperatif tipe TGT berbantuan media game online dengan peningkatan kemampuan penalaran matematis siswa yang mendapatkan pembelajaran langsung.

Berdasarkan kesimpulan dan temuan lainnya pada analisis data, maka peneliti merekomendasikan beberapa saran sebagai berikut:

1. Untuk efektivitas penggunaan media game online pada saat pembelajaran, siswa diharapkan sudah memiliki kecakapan untuk mengoperasikan komputer. Selain itu, fasilitas komputer yang tersedia di sekolah dapat ikut menunjang proses pembelajaran. Pada penelitian ini, fasilitas komputer yang tersedia ada 4 buah laptop yang terhubung dengan internet dan digunakan oleh 4 kelompok siswa. Untuk itu disarankan bagi peneliti lain sebaiknya melakukan penelitian sejenis dengan fasilitas komputer yang lebih lengkap sehingga masing-masing siswa dapat mengoperasikannya, tidak sebatas digunakan secara berkelompok.

2. Perbedaan peningkatan kemampuan pemahaman konsep dan penalaran matematis ini berkaitan dengan materi bangun ruang, hal ini tidak berarti bahwa peningkatan tersebut berlaku pula pada materi lain atau kemampuan matematis lainnya. Untuk itu disarankan bagi peneliti yang lain, sebaiknya melakukan penelitian sejenis menggunakan model pembelajaran kooperatif tipe TGT berbantuan media game online dengan meneliti kemampuan matematika lainnya selain kemampuan pemahaman konsep dan penalaran matematis atau menggunakan materi yang berbeda untuk diteliti, misalnya materi tentang bangun datar.

\section{DAFTAR PUSTAKA}

Affandi, M. (2013). Pengaruh game online terhadap tingkat efektivitas komunikasi interpersonal pada kalangan pelajar kelas 5vSDN 009 Samarinda. E-Jurnal Ilmu Komunikasi, 1(4), hlm 111-187.

Akpan, Joseph. P,. \& Beard, Lawrence. A. (2014). Assistive technology and mathematics education. Universal Journal of Educational Research, 2(3), hlm 219-222.

Brodie, Karin. (2010). Teaching Mathematical Reasoning in Secondary School Classroom. New York: Springer.

Creswell, John W. (2012). Educational Research: Planning, Conducting, and Evaluating Quantitative and Qualitative Research. Pearson.

Departemen Pendidikan Nasional. (2006). Peraturan Menteri Pendidikan Nasional RI No. 22 Tahun 2006 tentang Satuan Isi untuk Satuan 
Pendidikan Dasar dan Menengah. Jakarta: Depdiknas.

Dourda, K., Bratitsis, T., Griva, E., \& Papadopoulou, P. (2014). Content and language integrated learning through an online game in Primary School: A case study. Electronic Journal of e-Learning, 12(3), hlm 243-258.

Huda, M. (2011). Cooperative Learning: Metode, Teknik, Struktur, dan Model Penerapan. Yogyakarta: Pustaka Belajar.

Katmada, A., Mavridis, A., \& Tsiatsos, T. (2014). Implementing a game for supporting learning in mathematics. Electronic Journal of e-Learning, 12(3), hlm 230-242.

Kilpatrick, J., Swafford, J., \& Findell, B. (2001). Adding It Up: Helping Children Learn Mathematics. Washington DC: National Academy Press.

Lie, A. (2008). Cooperative Learning: Mempraktikkan Cooperative Learning di Ruang-ruang Kelas. Jakarta: Grasindo.

Main, S., \& O'Rouke, J. (2011). New directions for traditional lessons: can handheld game consoles enhance mental mathematics skills?. Australian Journal of Teacher Education, 36(2), hlm 4355.

National Council of Teachers of Mathematics. (2000). Prinsiples and Standards for School Mathematics. Reston: NCTM.

Nurdiansyah, S. (2014). Penerapan model pembelajaran kooperatif tipe tgt (teams games tournament) untuk meningkatkan hasil belajar siswa pada materi pokok operasi bilangan pecahan. Jurnal Mahasiswa Teknologi Pendidikan, 1(1), hlm. 110.

Patahuddin, Siti M. \& Rokhim, Alfath F. (2009). Website permainan matematika online untuk belajar matematika secara menyenangkan. Jurnal Pendidikan Matematika, 3(2), hlm 103-111.

Purnamasari, Y. (2014). Pengaruh model pembelajaran kooperatif tipe teams games tournament (TGT) terhadap kemandirian belajar dan peningkatan kemampuan penalaran dan koneksi matematis peserta didik smpn 1 kota tasikmalaya. Jurnal Pendidikan dan Keguruan, 1(1), hlm 43-55.

Purwanto, M. N. (1994). Prinsip-prinsip dan teknik evaluasi pengajaran. Bandung: Rosdakarya.

Riyanto, B. (2011). Meningkatkan kemampuan penalaran dan prestasi matematika dengan pendekatan konstruktivisme pada siswa sekolah menengah atas. Jurnal Pendidikan Matematika,5(2), hlm. 111-127.

Ruseffendi, E.T. (2006). Pengantar kepada membantu guru mengembangkan kompetensinya dalam pengajaran matematika untuk meningkatkan CBSA. Bandung: Tarsito

Rusman. (2012). Model-model Pembelajaran. Jakarta: Raja Grafindo Persada.

Sari, D.P., \& Rahardi, R. (2012). Peningkatan keaktifan dan hasil belajar siswa kelas XI IPS 2 SMAN 1 Turen pada pokok bahasan turunan dengan pembelajaran kooperatif tipe Teams Games Tournament (TGT). Jurnal Univesitas Negeri Malang, 1(3), hlm 43-55.

Sanjaya, W. (2006). Strategi pembelajaran berorientasi standar proses pendidikan. Jakarta: Kencana Prenada Media.

Santrock. J.W. (2010). Psikologi Pendidikan. Jakarta: Kencana Prenada Media Group.

Shadiq, Fadjar. (2004). Pemecahan Masalah, Penalaran dan Komunikasi. Disampaikan pada 
Diklat Instruktur/Pengembang Matematika SMA Jenjang Dasar Tanggal 6 s.d. 19 Agustus 2004 di PPPG Matematika. Yogyakarta: Departemen Pendidikan Nasional Direktorat Jenderal Pendidikan Dasar dan Menengah Pusat Pengembangan Penataran Guru (PPPG) Matematika Yogyakarta.

Skemp, R. R. (1976) Relational Understanding and Instrumental Understanding. Mathematics Teaching, 77, 20-26.

Slavin, R.E. (2009). Cooperative Learning: Teori, Riset dan Praktik. Bandung: Nusamedia.

Sulistyowati. (2013). Analisis kesalahan mengerjakan soal geometri pada siswa kelas V SD/MI di kota yogyakarta. E-Jurnal UNY, 1(2), hlm. 1-23.

Turmudi. (2008). Landasan Filsafat dan Teori Pembelajaran Matematika. Jakarta: Leuser Cita Pustaka.

Turmudi. (2009). Modul 4, BangunBangun Geometri Di Bidang Datar. [Online]. Diakses dari: http://file.upi.edu/Direktori/

Van De Walle, J. A. (2008). Matematika sekolah dasar dan menengah. (Dr. Suyono, M.Si. Terjemahan). Jakarta: Erlangga.

Wahyudin. (2008). Pembelajaran dan model-model pembelajaran. Jakarta: CV IPA Abong. 